\title{
The complexities of insulin allergy: a case and approach
}

\author{
Babak Aberumand ${ }^{1 *}$ (D) and Samira Jeimy ${ }^{2}$
}

\begin{abstract}
Background: Insulin hypersensitivity is rare, but challenging for individuals with diabetes. The prevalence of insulin allergy has decreased since the introduction of human recombinant insulin preparations. Hypersensitivity reactions range from injection site erythema and swelling, to anaphylaxis. While some reactions are to excipients (zinc, protamine, metacresol), many are to recombinant insulin itself. We present a case of type 1 hypersensitivity to various preparations of insulin in a patient with insulin-dependent type 2 diabetes mellitus (T2DM).

Case presentation: A 61-year-old woman with a 30-year history of insulin-dependent T2DM was referred for evaluation of reactions to insulin. She had two episodes over 5-months; both required Emergency Department visits and epinephrine administration. The first episode entailed a burning sensation of the extremities and nausea, immediately after injecting NovoRapid ${ }^{\circledR}$ insulin. The second event entailed a similar reaction but this time there was also angioedema of the upper airway with difficulty breathing and hypotension, immediately after injecting Levemir ${ }^{\circledR}$ and NovoRapid ${ }^{\circledR}$, and taking metformin. There were no cofactors such as exercise, infectious illness, or NSAIDs use. Skin testing was performed with metformin, Lantus ${ }^{\circledR}$, Humalog $^{\circledR}$, NovoRapid $^{\circledR}$, glulisine, insulin regular, NPH, Levemir $^{\circledR}$ and the excipient protamine, as per published testing concentrations. Metacresol was not tested as its use was restricted by the hospital pharmacy. Insulin preparations with and without metacresol were included in testing however. A clinic staff served as a negative control. The patent had negative testing with protamine, but sensitization to all insulin preparations. Metformin skin testing and challenge along with latex IgE were negative. Subsequently, she underwent intentional weight loss of $70 \mathrm{lb}$, and was started on oral hypoglycemics with good effect.
\end{abstract}

Conclusions: Our case highlights the importance of diagnosing insulin allergy through a detailed history and focused testing. Therapeutic strategies include avoidance and insulin alternatives, alternate insulin preparations, or desensitization. In severe recurrent hypersensitivity reactions, Omalizumab or pancreatic transplantation have been effective.

Keywords: Insulin allergy, Anaphylaxis, Diabetes mellitus, Type I hypersensitivity

\section{Introduction}

Insulin is a polypeptide hormone produced by beta cells of the pancreatic islets in response to hyperglycemia, and is heavily involved in the regulation of serum glucose levels [1]. It is used as the mainstay of treatment

*Correspondence: baberumand2016@meds.uwo.ca

${ }^{1}$ Division of Allergy and Immunology, Department of Medicine, University of Toronto, 30 Bond St. M5B 1W8, Toronto, ON, Canada Full list of author information is available at the end of the article in type 1 diabetes mellitus (T1DM) and severe T2DM patients with poor glycemic control despite maximal oral hypoglycemics therapy [2, 3]. Hypersensitivity reactions to insulin are rare but Type I, Type III and Type IV hypersensitivity reactions have been described. IgEmediated reactions classically occurring within 1 hour of injection [4, 5]. Signs and symptoms range from localized erythema and swelling at the site of injection to severe generalized reactions such as anaphylaxis $[6,7]$. Hypersensitivity reactions to insulin were significantly original author(s) and the source, provide a link to the Creative Commons licence, and indicate if changes were made. The images or other third party material in this article are included in the article's Creative Commons licence, unless indicated otherwise in a credit line to the material. If material is not included in the article's Creative Commons licence and your intended use is not permitted by statutory regulation or exceeds the permitted use, you will need to obtain permission directly from the copyright holder. To view a copy of this licence, visit http://creativecommons.org/licenses/by/4.0/. The Creative Commons Public Domain Dedication waiver (http://creativeco mmons.org/publicdomain/zero/1.0/) applies to the data made available in this article, unless otherwise stated in a credit line to the data. 
more prevalent in animal preparations of insulin such as bovine and porcine insulins. However, with the introduction of human recombinant insulin, and minor modifications from the amino acid sequence of human insulin, the prevalence of insulin hypersensitivity reactions has significantly decreased and is estimated at less than $2.4 \%$ in patients on insulin therapy [8].

Despite recombinant human insulin being the culprit in some of the cases of insulin allergy [9], patients may also react to the inactive excipients such as protamine, zinc or metacresol in the insulin preparations $[8,10,11]$. Therapeutic options in patients with insulin allergy can thus be challenging. In the present study, we describe a case of a woman with T2DM on insulin for over 30 years who experienced two immediate reactions following the administration of NovoRapid ${ }^{\circledR}$ insulin and subsequently Levemir $^{\circledR}$ and NovoRapid ${ }^{\circledR}$ insulin. We provide an approach to evaluating patients with a hypersensitivity reaction to insulin and an overview of the management options currently available.

\section{Case presentation}

A 61-year-old woman was referred to the Allergy Clinic at Western University for evaluation of an IgEmediated reaction to insulin. She had two episodes over a 5-month period that required a visit to the Emergency Department (ED), requiring treatment with epinephrine to achieve resolution of her symptoms. The first event she experienced entailed a burning sensation in her hands and feet with nausea immediately after injecting NovoRapid ${ }^{\circledR}$ insulin subcutaneously. The second event caused a similar reaction but there was also throat swelling and difficult breathing immediately after taking metformin, Levemir ${ }^{\circledR}$ and NovoRapid ${ }^{\circledR}$. There was no rash, vomiting, diarrhea or loss of consciousness. In the ED, she was found to be hypotensive. There were no cofactors such as exercise or other medications including NSAIDs taken at the time of these reactions. On both occasions, the insulin used were from a fresh vial stored in her refrigerator. She did not have any previous reactions to insulin and had been on the same medication for over 30 years without missing any doses. She had a medical history comprising of longstanding T2DM with a recent hemoglobin A1c level of 8.9\%, Lyme disease in 2018 and herpes zoster in 2019. There was no personal history of previous allergies to drugs or insect stings, atopy or autoimmune disease. Her medications included zopiclone $5 \mathrm{mg}$ once daily, detemir insulin 20 units every morning and Novorapid ${ }^{\circledR}$ insulin 10 units twice daily. Both forms of insulin were held after the reactions mentioned above.

In clinic, she underwent skin-prick testing (SPT) to metformin, Lantus ${ }^{\circledR}$, Humalog $^{\circledR}$, NovoRapid $^{\circledR}$, Apidra $^{\circledR}$,
Insulin Regular, NPH, Detemir, and the additive protamine. NPH was diluted 30 -fold to $333 \mu \mathrm{g} / \mathrm{mL}$ for testing, to approximate concentration in undiluted $\mathrm{NPH}$ insulin $(350 \mu \mathrm{g} / \mathrm{mL})$. Metacresol testing was not performed as its use was restricted by the hospital pharmacy but she had positive wheal and flare responses to non-metacresol-containing insulin preparations. Insulin preparations containing zinc and without zinc were included in testing. A positive skin-prick test was defined as a wheal size of greater than $3 \mathrm{~mm}$ than the negative control that developed within $15 \mathrm{~min}$. All skinprick test results were interpreted by an Allergist and Clinical Immunologist and validated with an appropriate histamine $(10 \mathrm{mg} / \mathrm{mL})$ positive control and saline negative control.

Positive SPT to the long-acting basal insulin Detemir was noted but negative to metformin, the other insulin formulations such as Lantus $^{\circledR}, \mathrm{NPH}$, Humalog $^{\circledR}$, Novorapid $^{\circledR}$, Apidra $^{\circledR}$, Insulin Regular, and the additive protamine (Fig. 1). Subsequently, intradermal testing at 1:10 and 1:100 dilutions with the various insulin preparations along with protamine at $3 \mathrm{mcg} / \mathrm{mL}$ and 0.3 $\mathrm{mcg} / \mathrm{m}$ indicated sensitization to all insulin preparations at both concentrations (Fig. 2). Protamine at both concentrations was negative. A positive intradermal skin test was defined as a wheal size of greater than $3 \mathrm{~mm}$ than the negative control that developed at least $15 \mathrm{~min}$ after the allergen was pricked to the skin of the participant's forearm. Again, the results of the intradermal skin testing were validated with an appropriate histamine $(10 \mathrm{mg} /$

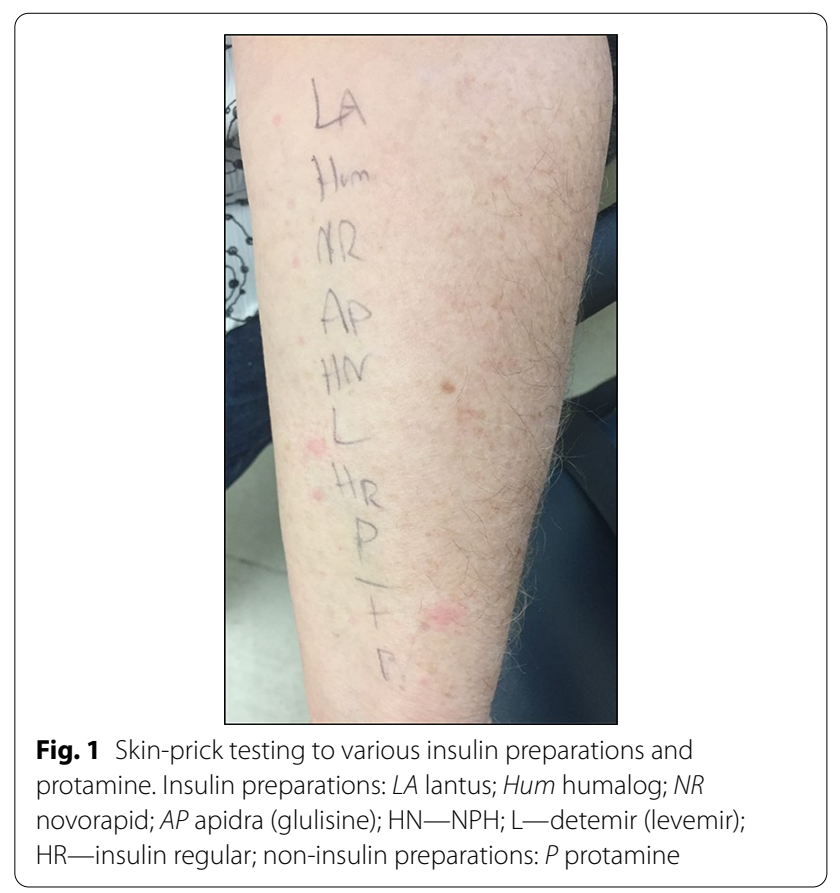




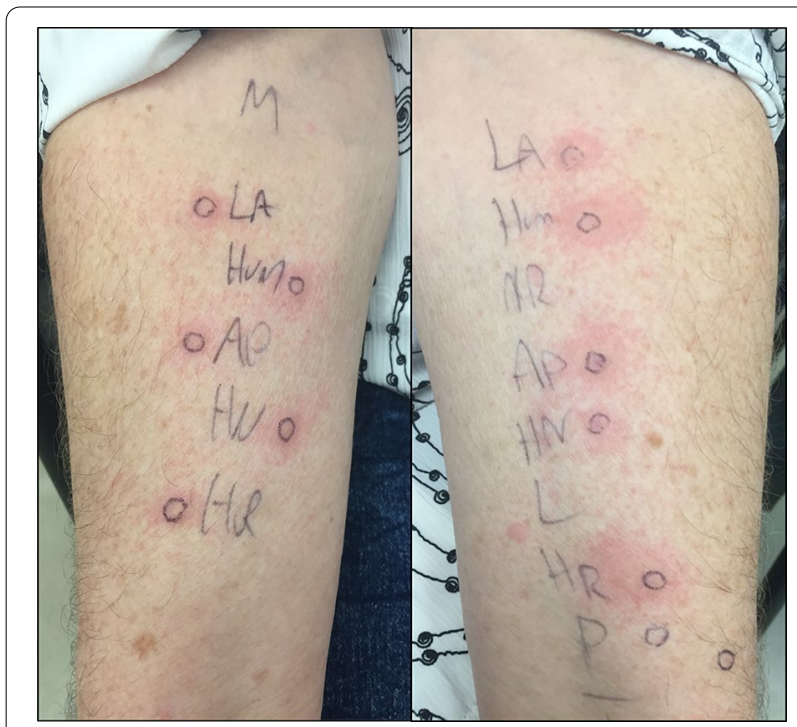

Fig. 2 Intradermal testing at 1:10 (left) and 1:100 dilutions (right) with the various insulin preparations and diluted protamine. Insulin preparations: LA lantus; Hum humalog; NR novorapid; AP apidra (glulisine); $\mathrm{HN}$ - NPH; L-detemir (levemir); HR—insulin regular; non-insulin preparations: $M$ meformin; $P$ protamine

$\mathrm{mL}$ ) positive control and saline negative control. Baseline and intermittent clinical exams, vital sign assessment, and blood glucose measurements were performed during the SPT and intradermal skin testing with no changes to the clinical exam. Blood glucose levels remained stable ranging from 9 to $12 \mathrm{mmol} / \mathrm{L}$. All tests were applied to a healthy volunteer for a negative control. Serum IgE insulin was elevated at $2.85 \mathrm{kU} / \mathrm{L}$. Serum tryptase and serum C4 levels were normal at $3.9 \mathrm{ng} / \mathrm{mL}$ and $0.34 \mathrm{~g} / \mathrm{L}$ respectively. Latex IgE level was also normal at $<0.1 \mathrm{kU} / \mathrm{L}$. Oral challenge to metformin was negative.

She was diagnosed with an IgE-mediated anaphylactic reaction to insulin and advised to avoid insulin, unless she underwent desensitization therapy in a monitored setting followed by continuous use of an insulin pump. Two epinephrine autoinjectors were provided and recommended to be on hand at all times after a discussion and shared decision making with the patient.

\section{Discussion and conclusion}

Since the introduction of the first recombinant human insulin, Humulin, the prevalence of insulin use has increased vastly [12], and various forms have been developed ranging from short-acting to long-acting (Table 1). Animal insulin formulations were significantly immunogenic, with bovine insulin being more likely to result in a reaction than porcine insulin $[1,13]$. However, since the introduction of recombinant human insulin, the immunogenicity has drastically decreased [5, 14].
Despite this, hypersensitivity reactions can still occur to various components of an insulin preparation including additives and preservatives such as zinc, protamine and metacresol, and also the insulin component as well [8-11].

\section{Clinical presentation}

Type I immediate hypersensitivity reactions are the most common type of allergic reaction to recombinant human insulin [5]. Typically, the reaction occurs 1 week after initiation of insulin therapy and typically within $1 \mathrm{~h}$ of administration. Biphasic reactions have occurred $4-6 \mathrm{~h}$ after the initial reaction [5, 7]. Patients on insulin therapy, who have interruptions in therapy ranging from months to years, have reported a Type I immediate hypersensitivity reaction after resuming insulin [7]. Type III [14] and Type IV reactions have also been described [5]. It is worthy to note that IgG antibodies are also involved in insulin resistance. Type IV hypersensitivity reactions tend to occur within $8-12 \mathrm{~h}$ of insulin use, peak at $24 \mathrm{~h}$ and last anywhere from 4 to 7 days [5, 7]. A case of a delayed reaction causing leukocytoclastic vasculitis in a patient with T1DM after recombinant insulin use has been reported [15]. Although extremely rare, local and systemic allergic reactions to endogenously secreted insulin in association with recombinant insulin therapy can occur [16].

\section{Pathogenesis}

The pathogenesis of hypersensitivity reactions secondary to insulin is not well understood. It has been proposed that insulin molecules congregate into larger molecules which facilitate the formation of anti-insulin antibodies in subcutaneous tissue [17-19]. Newer recombinant insulins have less antigenicity as they are more rapidly absorbed, and hence are unlikely to form these aggregates, resulting in less mast cell exposure and the potential for the development of anti-insulin antibodies $[20,21]$. The route of administration has also been suggested to play a role, with subcutaneous injections of insulin more likely to cause hypersensitivity as compared to intravenous injections [22]. Furthermore, genetics also seem to play a role as the HLA gene DR4 has been associated with high levels of insulin antibody formation [7].

\section{Work-up}

Workup of insulin allergy involves a thorough history and physical exam to exclude other potential culprits. It is worth noting that contamination of the insulin needle can occur with latex when insulin is being drawn up, as latex is commonly found in the insulin vial [23]. As a result, latex allergy should be excluded, or latex-free 
Table 1 Types of recombinant insulin with their respective clinically relevant non-medicinal ingredients

Recombinant insulin type (name and brand)

Bolus

Rapid-acting insulin analogues

Insulin aspart (NovoRapid ${ }^{\circledR}$ )

Insulin faster aspart $\left(\right.$ Fiasp $\left.^{\circledR}\right)$

Insulin lispro (Humalog ${ }^{\circledR}$, Humalog 100 units/mL)

Insulin lispro (Humalog ${ }^{\circledR}$, Humalog 200 units/mL)

Insulin lispro (Admelog $\left.{ }^{\circledR}\right)$

Insulin glulisine (Apidra ${ }^{\circledR}$ )

Short-acting Insulins

Insulin regular (Humulin $\mathrm{R}^{\circledR}$ )

\section{Clinically relevant non-medicinal ingredients}

Metacresol

Zinc chloride solution

Disodium phosphate dihydrate

Glycerol

Hydrochloric acid

Sodium chloride solution

Metacresol

Zinc acetate

Phenol

Disodium phosphate dihydrate

Glycerol

Hydrochloric acid

Sodium chloride solution

L-arginine $\mathrm{HCl}$

Niacinamide (vitamin $B_{3}$ )

Metacresol

Zinc (as ion)

Dibasic sodium phosphate

Glycerol

Hydrochloric acid

Sodium hydroxide

Metacresol

Zinc oxide

Sodium hydroxide

Glycerol

Hydrochloric acid

Tromethamine

Metacresol

Zinc oxide

Dibasic sodium phosphate

Glycerol

Hydrochloric acid

Sodium hydroxide

Metacresol

Sodium chloride

Polysorbate 20

Hydrochloric acid

Tromethamine

Metacresol

Sodium hydroxide

Glycerol

Hydrochloric acid 
Table 1 (continued)

Recombinant insulin type (name and brand)

Clinically relevant non-medicinal ingredients

Novolin ${ }^{\circledR}$ ge Toronto

Intermediate-acting insulins

Humulin $N^{\circledR}$

Novolin ${ }^{\circledR}$ ge NPH

Basal

Long-acting basal insulin analogues Insulin detemir (Levemir $\left.{ }^{\circledR}\right)$

Insulin glargine 100 units/mL (Lantus $\left.{ }^{\circledR}\right)$

Insulin glargine 100 units/mL (Basaglar ${ }^{\circledR}$ )

Insulin glargine 300 units $/ \mathrm{mL}\left(\right.$ Toujeo $\left.^{\circledR}\right)$

Insulin degludec (Tresiba ${ }^{\circledR}$ )
Metacresol

Zinc chloride

Glycerol

Sodium hydroxide

Hydrochloric acid

Protamine sulfate

Zinc oxide

Dibasic sodium phosphate

Phenol

Zinc chloride

Sodium hydroxide

Phenol

Disodium phosphate dihydrate

Metacresol

Zinc acetate

Glycerol

Sodium hydroxide

Phenol

Disodium phosphate dihydrate

Hydrochloric acid

Metacresol

Zinc

Glycerol 85\%

Polysorbate 20

Hydrochloric acid

Sodium hydroxide

Metacresol

Zinc oxide

Glycerol 85\%

Polysorbate 20

Hydrochloric acid

Sodium hydroxide

Metacresol

Zinc chloride

Glycerol 85\%

Hydrochloric acid

Sodium hydroxide

Metacresol

Zinc acetate

Glycerol

Phenol 
Table 1 (continued)

\begin{tabular}{|c|c|}
\hline Recombinant insulin type (name and brand) & Clinically relevant non-medicinal in \\
\hline \multicolumn{2}{|l|}{ Pre-mixed insulins } \\
\hline \multicolumn{2}{|l|}{ Premixed regular insulin } \\
\hline \multirow[t]{4}{*}{ Humulin 30/70 ${ }^{\circledR}$} & Protamine sulfate \\
\hline & Zinc oxide \\
\hline & Dibasic sodium phosphate \\
\hline & Phenol \\
\hline \multirow{8}{*}{$\begin{array}{l}\text { Novolin }{ }^{\circledR} \text { ge } 30 / 70 \\
\text { Novolin }{ }^{\circledR} \text { ge } 40 / 60 \\
\text { Novolin }{ }^{\circledR} \text { ge } 50 / 50\end{array}$} & Metacresol \\
\hline & Protamine sulphate \\
\hline & Zinc chloride \\
\hline & Disodium phosphate dihydrate \\
\hline & Glycerol \\
\hline & Phenol \\
\hline & Hydrochloric acid \\
\hline & Sodium hydroxide \\
\hline \multicolumn{2}{|l|}{ Premixed insulin analogues } \\
\hline \multirow[t]{9}{*}{ Biphasic insulin aspart (NovoMix $30^{\circledR}$ ) } & Protamine sulfate \\
\hline & Metacresol \\
\hline & Zinc chloride \\
\hline & Glycerol \\
\hline & Phenol \\
\hline & Sodium chloride \\
\hline & Dibasic sodium phosphate dihydrate \\
\hline & Sodium hydroxide, \\
\hline & Hydrochloric acid \\
\hline \multirow[t]{3}{*}{ Insulin lispro/lispro protamine (Humalog Mix $25^{\circledR}$, Humalog Mix $50^{\circledR}$ ) } & Protamine sulfate \\
\hline & Zinc oxide \\
\hline & Phenol \\
\hline
\end{tabular}

insulin vials should be used if suspicion is high for a latex allergy. Allergy to excipients zinc, protamine and metacresol used with different formulations of insulin have been described as a potential cause of systemic reactions, and should be evaluated with skin prick testing (SPT) [9-12]. However, intradermal skin testing can also be used to diagnose insulin allergy and has been suggested to be more sensitive than SPT to detect insulin allergy [7]. As in this case, if commercial skin test kits are not available, insulin and protamine can be diluted for use for SPT and intradermal testing as per published dilution recommendations outlined in Table 2 [24]. Skin test results should be interpreted in association with the clinical symptoms as false positives do occur and have been noted in $28 \%$ of diabetic patients with low specific IgE titers [10]. In fact, it has been postulated that as high as $40 \%$ of asymptomatic diabetic patients may have a positive skin test result or specific IgE to insulin [25]. The presence of specific IgE insulin is more supportive of a type 1 hypersensitivity reaction and its absence less likely so. Circulating IgE levels can be elevated or absent in patients with insulin

Table 2 Proposed skin testing concentrations

\begin{tabular}{|c|c|c|}
\hline \multirow[t]{2}{*}{ Component } & \multicolumn{2}{|l|}{ Recommended dilution } \\
\hline & SPT & Intradermal \\
\hline Insulin & No dilution & $1 / 100000-1 / 10$ dilution, then $1 / 1$ \\
\hline Expedient (protamine, metacresol, zinc) & $\begin{array}{l}\text { Vary depending on concentrations in insulin solutions. Attempt to dilute } \\
\text { according to these concentrations }\end{array}$ & 1/1000-1/10 dilution \\
\hline
\end{tabular}


hypersensitivity reactions and may be low in acute reactions due to consumption [26].

\section{Management}

The initial management of insulin anaphylaxis is similar to other forms of anaphylaxis; prompt administration of epinephrine is warranted. Cutaneous manifestations can be improved with the administration of second generation antihistamines. The use of systemic steroids can be considered, but special attention should be taken to monitor for hyperglycemia and insulin resistance. This can potentially increase exposure to the allergen as greater doses of insulin will be required. As well, the use of systemic steroids is not without risk of adverse side effects. Furthermore, evidence for corticosteroid or antihistamines to prevent a biphasic anaphylactic reaction is lacking $[26,27]$.

Long-term management of insulin allergy can be challenging and should involve a multidisciplinary team [28]. The mainstay of long-term management of insulin allergy is avoidance of insulin if possible or switching to another insulin preparation. In T2DM with confirmed insulin allergy, insulin should be switched to oral hypoglycemic agents if good glycemic control can be obtained [26]. Fortunately, this was successfully done with our patient as SPT and intradermal testing to other insulins was positive. Patients with confirmed sensitization to additives of commercial insulin preparations such as zinc, protamine or metacresol should be switched to a preparation that does not contain these excipients [9]. Unfortunately, in insulin-dependent conditions such as T1DM or acquired diabetics from a total pancreatectomy, insulin therapy is essential and discontinuing insulin is not feasible. As a result, switching to another insulin preparation that differs from the one that causes the insulin hypersensitivity reaction should be sought. Alternatively, insulin desensitization can be pursued, especially for those who are allergic to multiple forms of exogenous insulin. Tolerance is obtained through continuous or regular administration of incremental increasing doses of insulin analogues that typically have less antigenicity [3, 9, 20]. Longer acting insulin formulations for desensitization such as glargine have also been shown effective given its amino acid structure is less immunogenic and may actually inhibit immune reactions. Furthermore, glargine forms a slow dissolving precipitate after injection analogous to the antigen presentation with CSII [29]. Regular administration can be performed via intradermal, intravenous or subcutaneous injections [5, $9,22]$. The mechanism is believed to be centered around combination of decreased allergic mediators from mast cells through gradual stimulation of T-regulatory cells with incremental doses and the production of antiinsulin IgG-blocking antibodies [6, 9, 29]. The dose is increased in a graded fashion and has been shown to decrease symptoms and also IgE levels [9]. It is important to note that allergic symptoms can still persist despite the normalization of insulin-specific IgE and IgG levels [22]. Should a local allergic reaction occur, it is recommended that the dose at which the reaction occurred be repeated until there is resolution before increasing it. As opposed to a systemic reaction, where it is recommended that the dose be reduced to half of which caused the reaction [9]. Small doses of corticosteroids in the form of methylprednisolone $0.02 \mathrm{mg} / 1 \mathrm{U}$ insulin or hydrocortisone $10 \mathrm{mg}$ reduced to $2 \mathrm{mg}$ after 2 weeks of use, mixed with insulin have also been shown to be effective in reducing local allergic reactions. The blood sugar level was controlled and there was a potential for gradual discontinuation of the corticosteroids after a few months of use [30, 31].

During desensitization, blood sugar levels need to be closely monitored and any significant increases should be managed with an insulin pump with insulin preparations that differ from the one used for desensitization. In the event that high insulin doses are used, a glucose solution should be administered to offset the effects of high levels of insulin [9]. Although uncommon, it is worthy to note that the lasting effects of desensitization can be minimal and short-term with a potential of returning symptoms [32]. Furthermore, there is a possibility of developing insulin resistance through the development of IgG antibodies [33]. Several protocols have been created to help ease the process of insulin desensitization in an inpatient and outpatient setting [3, 24] (Tables 3, 4).

Continuous subcutaneous insulin infusion (CSII), first introduced in 1987, has also been shown to be effective and is typically implemented with a very low initial basal rate (i.e., $0.01 \mathrm{U} / \mathrm{h}$ ) and increased slowly as tolerated. Rapid-acting analogs such as insulin lispro and insulin aspart are typically used as they are shorter-acting which reduces their exposure to mast cells and allows for quicker absorption and degradation at the injection site leading to reduced immunologic effects $[3,4,29$, 34-36]. CSII has been proposed to be as effective as the traditional regimen of desensitization [3,37]. Concurrent intravenous insulin infusions should also be considered during the CSII to prevent diabetic ketoacidosis [38].

Despite desensitization, recurrence of insulin allergy can occur [32]. In these situations, treatment with Omalizumab (Xolair ${ }^{\circledR}$ ), an anti-IgE monoclonal antibody, has been successful in treating insulin allergy $[39,40]$. In fact, the use of two targeted biologics in a two-step approach has similarly been successful in alleviating severe insulin allergy. Initially Rituximab, a 
Table 3 Desensitization protocol by CSII with a short-acting insulin. Adapted from Yuan et al. [3]

\begin{tabular}{|c|c|c|c|}
\hline Day & Dose & Rate increase $^{a}$ & $\begin{array}{l}\text { Target rate at } \\
\text { the end of the } \\
\text { day }\end{array}$ \\
\hline 1 & $0.01 \mathrm{IU} / \mathrm{h}$ of dilute insulin ${ }^{\mathrm{b}}$ & $0.01 \mathrm{IU} / \mathrm{h}$ & $0.24 \mathrm{IU} / \mathrm{h}$ \\
\hline 2 & $0.25 \mathrm{IU} / \mathrm{h}$ of non-dilute insulin & $0.05 \mathrm{IU} / \mathrm{h}$ & $1.4 \mathrm{IU} / \mathrm{h}$ \\
\hline 3 & $1.0 \mathrm{IU} / \mathrm{h}^{\mathrm{c}}$ & \multicolumn{2}{|c|}{$\begin{array}{l}\text { Add } 4-6 \text { IU to the bolus insulin infusion before each } \\
\text { meal with the insulin pump }\end{array}$} \\
\hline 4 & \multicolumn{3}{|c|}{ Give the bolus insulin by subcutaneous injection using a syringe, with a CSII basal insulin infusion administered at the same time } \\
\hline & \multicolumn{3}{|c|}{ Stop using CSII and gave the patient insulin therapy by alternative multiple subcutaneous injections } \\
\hline
\end{tabular}

${ }^{a}$ Check blood glucose levels and vitals q1 $\mathrm{h}$

${ }^{\mathrm{b}}$ Short-action insulin preparation was diluted 10 times (from U100 to U10 by saline)

c Alternatively can decrease to $0.5 \mathrm{IU} / \mathrm{h}$ at night to avoid hypoglycemia in older patients

Table 4 Rapid desensitization protocol via subcutaneous insulin Glargine. Adapted from Hasani-Ranjbar et al. [24]

\begin{tabular}{|c|c|c|c|}
\hline Day & Dose & Time between doses & Recommendations \\
\hline 1 & $\begin{array}{l}\text { Administer } \\
0.0001 \mathrm{U} \\
0.001 \mathrm{U} \\
0.01 \mathrm{U}, 0.1 \mathrm{U} \\
1 \mathrm{U}\end{array}$ & 30-min intervals & Check blood glucose levels and vitals q30 min \\
\hline 2 & $\begin{array}{l}\text { Administer } 2 U \text {, } \\
4 U, 8 U \text { and } \\
20 U\end{array}$ & 30-min intervals & $\begin{array}{l}\text { In case of a local reaction, treat with an antihistamine and the last dose is repeated until no reaction } \\
\text { occurs and then the dose increases are continued } \\
\text { If there are systemic reactions, treat with epinephrine and an antihistamine. Reduce the dose to one half } \\
\text { At high insulin doses, a } 10 \% \text { glucose solution can be given to counteract the glucose-lowering effect }\end{array}$ \\
\hline
\end{tabular}

B-cell depleting monoclonal antibody, was given as the patient had levels of IgE too high to meet criteria for Omalizumab administration. Once the IgE levels were reduced with Rituximab, Omalizumab was administered [41]. In more severe cases of insulin allergy, refractory to the above management options, pancreas transplant or islet transplantation can be considered. However, this is a last resort given the invasiveness of these procedures and the long-term consequences [42, 43]. An algorithm to the workup and management of insulin allergy is outlined in Fig. 3.

In conclusion, although rare, our case illustrates the potential complexities of the management of insulin allergy. Fundamental to making an accurate insulin allergy diagnosis, is a thorough history and focused physical exam. Particular attention should be placed on the timing of symptoms after insulin administration with suspicion heightening with smaller gaps. Investigations should focus on ruling other potential explanations for the symptoms including latex allergy and allergy to excipients used in insulin preparations. SPT and intradermal testing to both short-acting and long-acting insulins should be conducted along with IgE levels specific to insulin. Treatment strategies include insulin avoidance, the use of oral hypoglycemics, the use of alternate insulin preparations and/or desensitization. In recurrent insulin hypersensitivity reactions after prior desensitization, treatment with Omalizumab and. depending on severity, pancreatic or islet transplantation should be explored. 


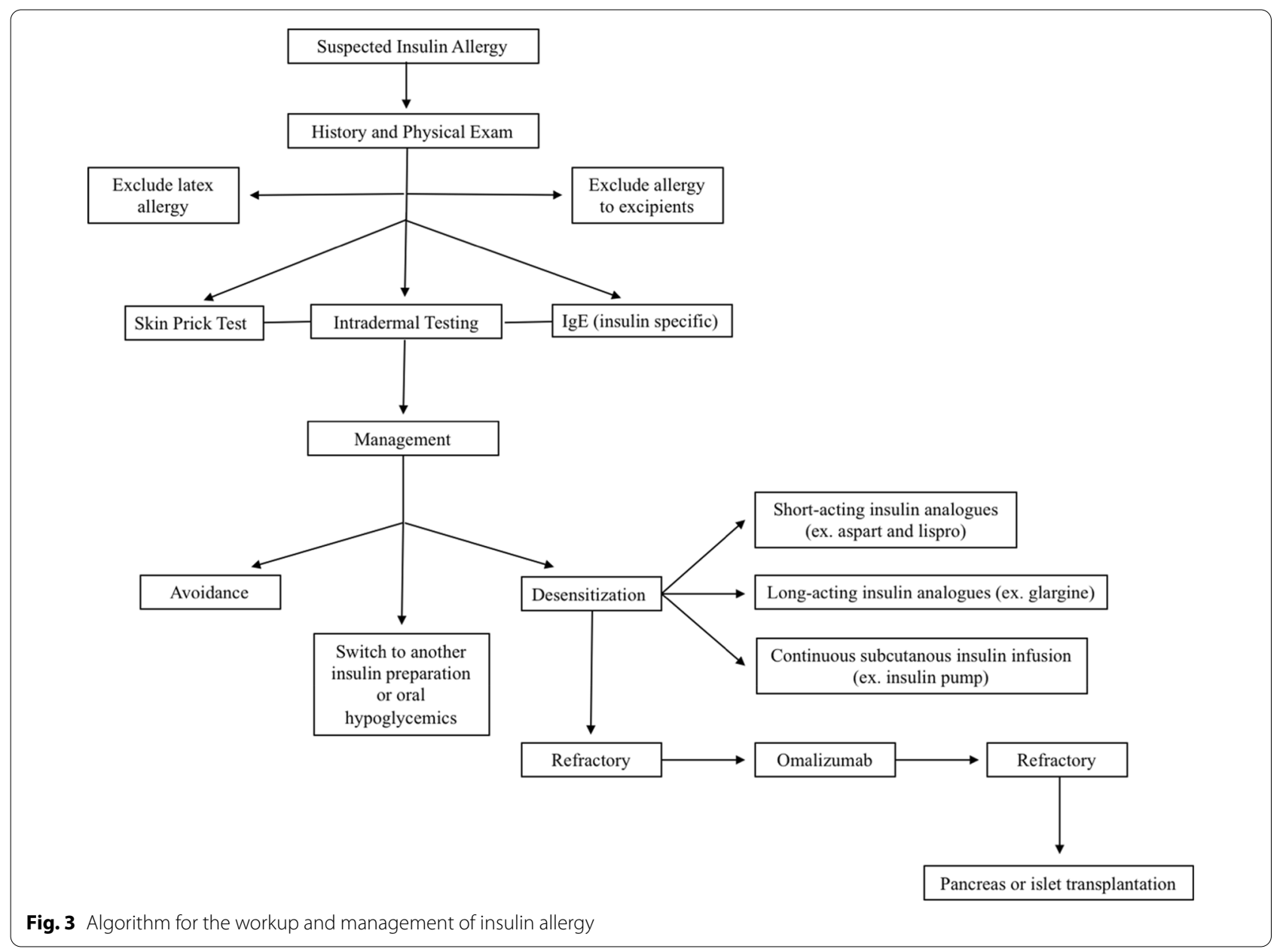

\section{Acknowledgements}

We thank our patient for allowing us to present her case and contribute it to the scientific literature.

\section{Authors' contributions}

Both the authors acknowledge that they have contributed significantly and are in agreement with the content of the manuscript. SJ obtained the information from the patient and BA was the primary manuscript writer. SJ was involved in reviewing the manuscript. Both the authors read and approved the final manuscript.

\section{Funding}

None.

\section{Availability of data and materials}

The authors will consider making the relevant anonymized patient level data and material available on reasonable request.

\section{Declarations}

\section{Ethics approval and consent to participate}

All procedures performed in studies involving human participants were in accordance with the ethical standards of the institutional and/or national research committee and with the 1964 Helsinki Declaration and its later amendments or comparable ethical standards. The patient gave their informed consent prior to publication. Consent to participate is available upon reasonable request.
Consent for publication

Obtained and available upon reasonable request.

\section{Competing interests}

The authors declare that they have no competing interests.

\section{Author details}

${ }^{1}$ Division of Allergy and Immunology, Department of Medicine, University of Toronto, 30 Bond St. M5B 1W8, Toronto, ON, Canada. ${ }^{2}$ Division of Allergy and Immunology, Department of Medicine, Western University, London, ON, Canada.

Received: 4 March 2021 Accepted: 3 May 2021

Published online: 29 July 2021

\section{References}

1. Ladisch MR, Kohlmann KL. Recombinant human insulin. Biotechnol Prog. 1992;8(6):469-78.

2. DiMeglio LA, Evans-Molina C, Oram RA. Type 1 diabetes. Lancet. 2018:391(10138):2449-62.

3. Yuan T, Zhao W, Wang L, Dong Y, Li N. Continuous subcutaneous insulin infusion as an effective method of desensitization therapy for diabetic patients with insulin allergy: a 4-year single-center experience. Clin Ther. 2016;38(11):2489-94. 
4. Castera V, Dutour-Meyer A, Koeppel MC, Petitjean C, Darmon P. Systemic allergy to human insulin and its rapid and long acting analogs: successful treatment by continuous subcutaneous insulin lispro infusion. Diabetes Metab. 2005;31(4):391-400.

5. Radermecker R, Scheen AJ. Allergy reactions to insulin: effects of continuous subcutaneous insulin infusion and insulin analogues. Diabetes Metab Res Rev. 2007;23(5):348-55.

6. Mastrorilli C, Rizzuti L, Cangelosi AM, lovane B, Chiari G, Caffarelli C. Longacting insulin allergy in a diabetic child. Int J Immunopathol Pharmacol. 2017;30(2):174-7

7. Schernthaner G. Immunogenicity and allergenic potential of animal and human insulins. Diabetes Care. 1993;16(Supplement 3):155-65.

8. Wheeler BJ, Taylor BJ. Successful management of allergy to the insulin excipient metacresol in a child with type 1 diabetes: a case report. J Med Case Rep. 2012;6(1):263

9. Heinzerling L, Raile K, Rochlitz H, Zuberbier T, Worm M. Insulin allergy: clinical manifestations and management strategies. Allergy. 2008;63(2):148-55.

10. Raap U, Liekenbröcker T, Kapp A, Wedi B. Delayed-type hypersensitivity to protamine as a complication of insulin therapy. Contact Dermat. 2005;53(1):57-8.

11. Feinglos $M$, Jegasothy B. "Insulin" allergy due to zinc. Lancet. 1979;313(8108):122-4

12. Sanchez-Garcia L, Martín L, Mangues R, Ferrer-Miralles N, Vázquez E, Villaverde A. Recombinant pharmaceuticals from microbial cells: a 2015 update. Microb Cell Fact. 2016;15(1):33.

13. Fernandez L, Duque S, Montalban C, Bartolome B. Allergy to human insulin. Allergy. 2003;58(12):1317.

14. deShazo RD, Boehm TM, Kumar D, Galloway JA, Dvorak HF. Dermal hypersensitivity reactions to insulin: correlations of three patterns to their histopathology. J Allergy Clin Immunol. 1982;69(2):229-37.

15. Mandrup-Poulsen T, Mølvig J, Pildal J, Rasmussen ÅK, Andersen L, Skov BG, Petersen J. Leukocytoclastic vasculitis induced by subcutaneous injection of human insulin in a patient with type 1 diabetes and essential thrombocytemia. Diabetes Care. 2002;25(1):242-3.

16. Alvarez-Thull L, Rosenwasser LJ, Brodie TD. Systemic allergy to endogenous insulin during therapy with recombinant DNA (rDNA) insulin. Ann Allergy Asthma Immunol. 1996;76(3):253-6.

17. Ratner RE, Phillips TM, Steiner M. Persistent cutaneous insulin allergy resulting from high-molecular-weight insulin aggregates. Diabetes. 1990;39(6):728-33.

18. Brange J, Andersen L, Laursen ED, Meyn G, Rasmussen E. Toward understanding insulin fibrillation. J Pharm Sci. 1997;86(5):517-25.

19. Maislos M, Mead PM, Gaynor DH, Robbins DC. The source of the circulating aggregate of insulin in type I diabetic patients is therapeutic insulin. J Clin Investig. 1986;77(3):717-23.

20. Hasselmann C, Pecquet C, Bismuth E, Raverdy C, Sola-Gazagnes A, Lobut JB, Carel JC, Tubiana-Rufi N. Continuous subcutaneous insulin infusion allows tolerance induction and diabetes treatment in a type 1 diabetic child with insulin allergy. Diabetes Metab. 2013;39(2):174-7.

21. Fineberg NS, Fineberg SE, Anderson JH, Birkett MA, Gibson RG, Hufferd S. Immunologic effects of insulin lispro [Lys (B28), Pro (B29) human insulin] in IDDM and NIDDM patients previously treated with insulin. Diabetes. 1996;45(12):1750-4.

22. Asai M, Yoshida M, Miura Y. Immunologic tolerance to intravenously injected insulin. N Engl J Med. 2006;354(3):307-9.

23. Roest MA, Shaw S, Orton DI. Insulin-injection-site reactions associated with Type I latex allergy. N Engl J Med. 2003;348(3):265-6.

24. Hasani-Ranjbar S, Fazlollahi MR, Mehri A, Larijani B. Allergy to human insulin and specific immunotherapy with glargine; case report with review of literature. Acta Diabetol. 2012;49(1):69-73.
25. Pérez E, González R, Martínez J, Iglesias J, Matheu V. Detemir insulininduced anaphylaxis. Ann Allergy Asthma Immunol. 2009;102(2):174-5.

26. Jacquier J, Chik CL, Senior PA. A practical, clinical approach to the assessment and management of suspected insulin allergy. Diabet Med. 2013;30(8):977-85.

27. Alqurashi W, Ellis AK. Do corticosteroids prevent biphasic anaphylaxis? J Allergy Clin Immunol Pract. 2017;5(5):1194-205.

28. Andrade P, Barros L, Gonçalo M. Type $1 \mathrm{lgE}$ mediated allergy to human insulin, insulin analogues and beta-lactam antibiotics. An Bras Dermatol. 2012;87(6):917-9.

29. Wu P, Ji C, Wang M, Zou S, Ge W. Desensitization of allergy to human insulin and its analogs by administering insulin aspart and insulin glargine. In: Annales d'endocrinologie; 2013. Vol. 74, No. 1. pp. 56-8.

30. Grant W, DeShazo RD, Frentz J. Use of low-dose continuous corticosteroid infusion to facilitate insulin pump use in local insulin hypersensitivity. Diabetes care. 1986;9(3):318-9.

31. Cockel R, Mann S. Insulin allergy treated by low-dosage hydrocortisone. British Med J. 1967:3(5567):722.

32. Chng HH, Leong KP, Loh KC. Primary systemic allergy to human insulin: recurrence of generalized urticaria after successful desensitization. Allergy. 1995;50(12):984-7.

33. Witters LA, Ohman JL, Weir GC, Raymond LW, Lowell FC. Insulin antibodies in the pathogenesis of insulin allergy and resistance. The American journal of medicine. 1977;63(5):703-9.

34. Gin H, Aubertin J. Generalized allergy due to zinc and protamine in insulin preparation treated with insulin pump. Diabetes Care. 1987;10(6):789-90.

35. Yokoyama H, Fukumoto S, Koyama H, Emoto M, Kitagawa Y, Nishizawa Y. Insulin allergy; desensitization with crystalline zinc-insulin and steroid tapering. Diabetes research and clinical practice. 2003;61(3):161-6.

36. Moyes V, Driver R, Croom A, Mirakian R, Chowdhury TA. Insulin allergy in a patient with Type 2 diabetes successfully treated with continuous subcutaneous insulin infusion. Diabetic medicine. 2006;23(2):204-6.

37. Näf S, Esmatjes E, Recasens M, Valero A, Halperin I, Levy I, Gomis R. Continuous subcutaneous insulin infusion to resolve an allergy to human insulin. Diabetes Care. 2002 Mar 1;25(3):634-5.

38. Matheu V, Perez E, Hernández M, Díaz E, Darias R, González A, García JC, Sánchez I, Feliciano L, Caballero A, De la Torre F. Insulin allergy and resistance successfully treated by desensitisation with Aspart insulin. Clinical and Molecular Allergy. 2005;3(1):16.

39. Matheu V, Franco A, Perez E, Hernández M, Barrios Y. Omalizumab for drug allergy. Journal of Allergy and Clinical Immunology. 2007;120(6):1471.

40. Mishra S, Connors L, Tugwell B. Role of omalizumab in insulin hypersensitivity: a case report and review of the literature. Diabetic Medicine. 2018;35(5):663-6.

41. Yong PF, Malik R, Arif S, Peakman M, Amiel S, Ibrahim MA, Gough A. Rituximab and omalizumab in severe, refractory insulin allergy. New England J Med. 2009;360(10):1045-7.

42. Malaise J, Leonet J, Goffin E, Lefebvre C, Tennstedt D, Vandeleene B, Buysschaert M, Squifflet JP. Pancreas transplantation for treatment of generalized allergy to human insulin in type 1 diabetes. In: Transplantation proceedings; 2005. Vol. 37, No. 6. pp. 2839.

43. Léonet J, Malaise J, Squifflet JP. Refractory insulin allergy: pancreas transplantation or immunosuppressive therapy alone?. Transplant Int. 2010;23(7):e39-40.

\section{Publisher's Note}

Springer Nature remains neutral with regard to jurisdictional claims in published maps and institutional affiliations. 